Abstract AB1298 - Table 1. Prevalence of rheumatic diseases distributed by city

\begin{tabular}{|c|c|c|c|c|c|c|c|c|}
\hline & Men & Women & Bogotá & Medellín & Cali & B/quilla & $\begin{array}{c}\mathrm{B} / \\
\text { manga }\end{array}$ & Cúcuta \\
\hline $\begin{array}{l}\text { Non-specific } \\
\text { musculoskeletal disease }\end{array}$ & $15,99 \%$ & $16,50 \%$ & $14,67 \%$ & $14,64 \%$ & $17,16 \%$ & $21,88 \%$ & $20,43 \%$ & $26,15 \%$ \\
\hline Osteoarthritis & $11,13 \%$ & $20,31 \%$ & $17,98 \%$ & $17,07 \%$ & $11,06 \%$ & $10,60 \%$ & $14,22 \%$ & $16,78 \%$ \\
\hline Mechanical Low Back pain & $8,58 \%$ & $8,19 \%$ & $10,15 \%$ & $4,39 \%$ & $5,23 \%$ & $11,91 \%$ & $3,82 \%$ & $11,68 \%$ \\
\hline Rheumatoid arthritis & $0,95 \%$ & $2,89 \%$ & $2,60 \%$ & $0,69 \%$ & $2,22 \%$ & $1,19 \%$ & $0,80 \%$ & $1,04 \%$ \\
\hline $\begin{array}{l}\text { Rheumatic Regional Pain } \\
\text { Syndromes }\end{array}$ & $0,96 \%$ & $1,96 \%$ & $2,67 \%$ & $0,32 \%$ & $0,10 \%$ & $0,26 \%$ & $0,23 \%$ & - \\
\hline Fibromyalgia & $0,05 \%$ & $2,27 \%$ & $1,29 \%$ & $1,09 \%$ & $1,41 \%$ & $1,07 \%$ & $0,44 \%$ & $1,34 \%$ \\
\hline $\begin{array}{l}\text { Inflammatory Low Back } \\
\text { Pain }\end{array}$ & $1,08 \%$ & $0,72 \%$ & $1,29 \%$ & $0,49 \%$ & $0,47 \%$ & $0,43 \%$ & - & $0,83 \%$ \\
\hline Gout & $1,28 \%$ & $0,05 \%$ & $1,09 \%$ & - & - & - & $0,27 \%$ & $1,34 \%$ \\
\hline $\begin{array}{l}\text { Undifferentiated } \\
\text { spondyloarthritis }\end{array}$ & $0,42 \%$ & $0,62 \%$ & $0,82 \%$ & - & $0,37 \%$ & $0,38 \%$ & - & $0,29 \%$ \\
\hline Ankylosing spondylitis & $0,96 \%$ & $0,08 \%$ & $0,08 \%$ & $2,20 \%$ & $0,47 \%$ & - & - & - \\
\hline Undifferentiated arthritis & $0,14 \%$ & $0,46 \%$ & $0,09 \%$ & $0,56 \%$ & $0,19 \%$ & $0,48 \%$ & $0,78 \%$ & $1,97 \%$ \\
\hline $\begin{array}{l}\text { Systemic lupus } \\
\text { erythematosus }\end{array}$ & - & $0,41 \%$ & $0,22 \%$ & $0,29 \%$ & $0,16 \%$ & $0,36 \%$ & - & - \\
\hline Sjogren's syndrome & $0,04 \%$ & $0,28 \%$ & $0,24 \%$ & - & $0,16 \%$ & $0,23 \%$ & - & - \\
\hline Systemic sclerosis & - & $0,04 \%$ & $0,04 \%$ & - & - & - & - & - \\
\hline
\end{tabular}

\section{AB1295 ASSOCIATION OF SHARED EPITOPE AND POOR PROGNOSTIC FACTORS IN RA}

E. Alemao ${ }^{1}$, Z. Guo ${ }^{1}$, J. Bryson ${ }^{1}$, C. lannaccone ${ }^{2}$, M. Frits ${ }^{2}$, N.A. Shadick ${ }^{2}$, M. E. Weinblatt ${ }^{2}{ }^{1}$ Bristol-Myers Squibb, Princeton; ${ }^{2}$ Brigham and Women's Hospital, Boston, USA

Background: Strong genetic association has been reported between RA and human leukocyte antigen (HLA) regions, particularly HLA-DRB1 alleles with the shared epitope (SE). SE alleles are associated with seropositivity, erosions and higher disease activity (DA) in RA.

Objectives: To evaluate the association between SE alleles and the presence of multiple poor prognostic factors (PPFs) of seropositive (anti-citrullinated protein antibody [ACPA] and/or RF) and erosive RA; as well as changes in DA.

Methods: We analysed patients (pts) enrolled in a large sequential RA registry established in 2003; most had established RA and annual clinical evaluations. Pts with baseline (BL) data on SE status were included. A commercially available kit (Qiagen, USA) was used for HLA genotyping. HLA-DRB1 serotypes were assessed from DNA sequences using allele-specific polymerase chain reaction methods and categorised as pts with no, 1 or 2 SE alleles. Changes from BL were compared in pts with vs without SE alleles. The association of multiple PPFs and SE status was evaluated using multinomial logistic models. The association between change in DA and SE status was analysed using linear regression models with age, sex, disease duration (DD), co-morbidities and biologic DMARDs as covariates.

Abstract AB1295 - Table 1. Baseline Characteristics by SE status

\begin{tabular}{lccc}
\hline & $\begin{array}{c}\text { No SE alleles } \\
(\mathbf{n}=\mathbf{2 4 1})\end{array}$ & $\begin{array}{c}\text { 1 SE allele } \\
(\mathbf{n}=\mathbf{2 7 5})\end{array}$ & $\begin{array}{c}\text { 2 SE alleles } \\
(\mathbf{n}=\mathbf{1 7 3})\end{array}$ \\
\hline Mean (SD) age, years & $57.7(13.6)$ & $58(13.9)$ & $57.8(13.6)$ \\
Female, $\mathbf{n}$ (\%) & $202(83.8)$ & $219(79.6)$ & $141(81.5)$ \\
Mean (SD) RA duration, years & $12.9(12.1)$ & $17(13.3)$ & $16.1(12.2)$ \\
Biologic DMARDs, $\mathbf{n}(\%)$ & $83(34.4)$ & $145(52.7)$ & $83(48.0)$ \\
ACPA+, $\mathbf{n}$ (\%) & $118(49.0)$ & $196(71.3)$ & $137(79.2)$ \\
Erosions, $\mathbf{n}(\%)$ & $116(48.1)$ & $168(61.1)$ & $114(65.9)$ \\
RF+, $\mathbf{n}(\%)$ & $120(49.8)$ & $195(70.9)$ & $128(74.0)$ \\
Double positive, $\mathbf{n}(\%)$ & $100(41.5)$ & $174(63.3)$ & $121(69.9)$ \\
DAS28 (CRP), mean (SD) & $3.8(1.5)$ & $4.2(1.6)$ & $4.3(1.6)$ \\
\hline
\end{tabular}

Abstract AB1295 - Table 2. Multivariate Analysis of Impact of SE Status on Change in DA

\begin{tabular}{|c|c|c|c|c|c|c|}
\hline & \multicolumn{2}{|c|}{ DAS28 (CRP) model } & \multicolumn{2}{|c|}{ CDAl model } & \multicolumn{2}{|c|}{ SDAI model } \\
\hline & Coefficient & $\begin{array}{c}\mathbf{p} \\
\text { value }\end{array}$ & Coefficient & $\begin{array}{c}\mathbf{p} \\
\text { value }\end{array}$ & Coefficient & $\begin{array}{c}\mathrm{p} \\
\text { value }\end{array}$ \\
\hline $\begin{array}{l}1 \text { or } 2 \text { SE alleles } \\
\text { (vs no SE) }\end{array}$ & 0.24 & 0.031 & 2.71 & 0.027 & 3.25 & 0.013 \\
\hline Baseline DA & -0.41 & $<0.001$ & -0.46 & $<0.001$ & -0.48 & $<0.001$ \\
\hline Age, years & 0.01 & 0.271 & 0.04 & 0.367 & 0.04 & 0.406 \\
\hline Female (vs male) & 0.11 & 0.435 & 2.52 & 0.099 & 2.12 & 0.198 \\
\hline $\begin{array}{l}\text { No. of co- } \\
\text { morbidities }\end{array}$ & 0.11 & 0.003 & 1.25 & 0.003 & 1.42 & 0.002 \\
\hline $\begin{array}{l}\text { Biologic DMARD } \\
\text { (yes vs no) }\end{array}$ & 0.41 & $<0.001$ & 3.79 & 0.002 & 4.09 & 0.001 \\
\hline $\begin{array}{l}\text { Adjusted R- } \\
\text { square }\end{array}$ & \multicolumn{2}{|c|}{0.23} & \multicolumn{2}{|l|}{0.27} & \multicolumn{2}{|l|}{0.29} \\
\hline
\end{tabular}

Results: Of 689 RA pts included, no, 1 and 2 SE alleles were reported in 241 (35.0\%), 275 (40.0\%) and 173 (25.1\%) pts, respectively. At BL, pts with SE alleles (vs no SE) were more likely to have PPFs, and had longer DD and higher DA (table 1). The odds ratio (OR) for seropositive erosive RA in pts with 2 and $1 \mathrm{SE}$ alleles (vs no SE) was $5.44(95 \% \mathrm{Cl} 2.39,12.39)$ and $2.87(1.32,6.23$; Fig), respectively. The OR for double seropositivity in pts with 2 and $1 \mathrm{SE}$ alleles (vs no SE) was $4.27(95 \% \mathrm{Cl} 2.51,7.28)$ and $2.56(1.66,3.94)$, respectively. A total of 551 pts had DA measures at BL and 1 year follow-up. After controlling for BL covariates, pts with SE (vs no SE) had an average increase in DAS28 (CRP) of $0.24(p=0.031)$, CDAl of 2.71 ( $p=0.027)$ and SDAI of 3.25 ( $p=0.013$; Table 2$)$.

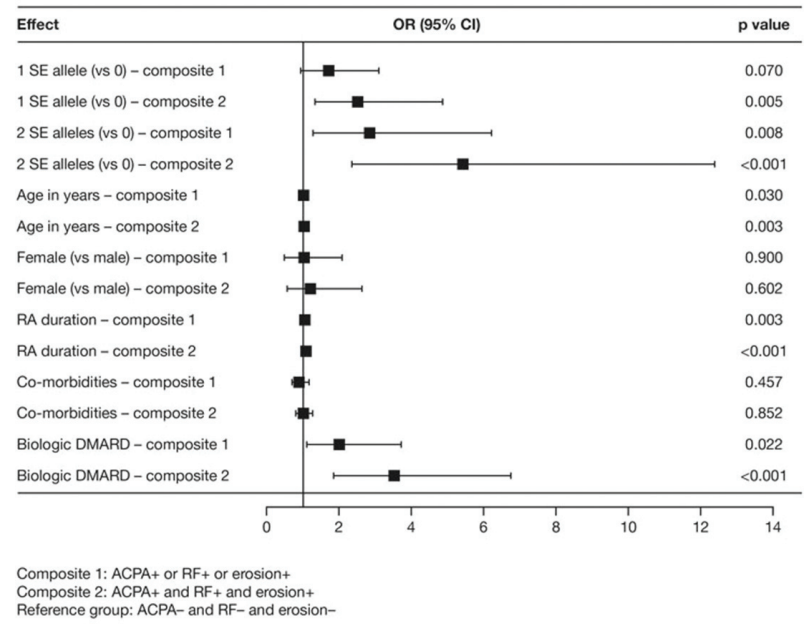

Abstract AB1295 - Figure 1. Multinomial Model for Multiple PPFs (Seropositive and Erosions)

Conclusions: Pts with (vs without) SE alleles are more likely to have multiple PPFs; pts with 2 SE alleles are 5 times more likely to be seropositive with erosive RA and 4 times more likely to be double positive. Pts with (vs without) SE alleles also experienced an increase in DA over time with standard-of-care treatment.

Disclosure of Interest: E. Alemao Shareholder of: Bristol-Myers Squibb, Employee of: Bristol-Myers Squibb, Z. Guo Employee of: Bristol-Myers Squibb, J. Bryson Shareholder of: Bristol-Myers Squibb, Employee of: Bristol-Myers Squibb, C. Iannaccone: None declared, M. Frits: None declared, N. Shadick Grant/ research support from: BRASS registry, Amgen, Bristol-Myers Squibb, and Mallinckrodt, Consultant for: Bristol-Myers Squibb, M. Weinblatt Grant/research support from: Bristol-Myers Squibb, Amgen, Crescendo Bioscience, Sanofi, Consultant for: Bristol-Myers Squibb, Amgen, Crescendo Bioscience, AbbVie, Eli Lilly, Pfizer, Roche, Merck, Samsung, Novartis

DOI: 10.1136/annrheumdis-2018-eular.1657 